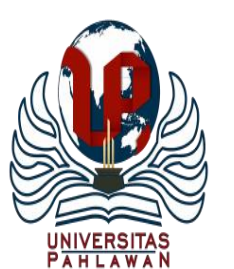

Edukatif : Jurnal Ilmu Pendidikan Volume 2 Nomor 2 Tahun 2020 Halm 113-120

EDUKATIF: JURNAL ILMU PENDIDIKAN

Research \& Learning in Education

https://edukatif.org/index.php/edukatif/index

\section{Kebijakan Pengembangan Keprofesian Berkelanjutan (PKB) Guru}

\author{
Kurnia Puspita Sari ${ }^{1}$, Sufyarma Marsidin ${ }^{2}$, Ahmad Sabandi ${ }^{3}$ \\ Universitas Negeri Padang, Sumatera Barat, Indonesia ${ }^{1,2,3}$ \\ E-mail: kurniapuspitasari248@gmail.com ${ }^{1} \underline{\text { sufyarma1954@gmail.com }} \underline{\text { sabandi@fip.unp.ac.id }}$
}

\begin{abstract}
Abstrak
Penelitian ini bertujuan untuk mengetahui kebijakan PKB guru di SD. Metode kepustakaan (library research) digunakan sebagai metodologi penelitian dalam penelitian ini. Teknik pengumpulan data dalam pembahasan ini yaitu dengan mengkaji atau mengeksplorasi beberapa buku, jurnal serta dokumen lain yang dianggap relevan. Penelitian ini membahas tentang hal yang penting dalam pendidikan yaitu bagaimana bentuk pelaksanaan PKB dalam pendidikan, Penyelenggaraan PKB sesuai dengan aturan maka dapat meningkatkan mutu pendidikan terutama di SD. PKB yaitu suatu pembelajaran yang dilaksanakan secara berkesinambungan oleh pendidik pada upaya mewujudkan perubahan berhubungan dengan kesuksesan siswa sehingga siswa memiliki ilmu, keterampilan serta dapat mengetahui materi secara lebih optimal. Melalui program PKB maka pendidik dapat meningkatkan motivasi siswa terlebih dalam bidang IPTEKS. Guru yang kompeten sangat dibutuhkan untuk menunjang pembangunan negara secara komprehensif karena dapat menghasilkan orang-orang cerdas.
\end{abstract}

Kata kunci: PKB, guru, pendidikan

\begin{abstract}
The purpose of this discussion is to find out the PKB policy of teachers in elementary schools. The library research method is used as a research methodology in this study. Data collection techniques in this discussion is to review or explore several books, journals and other documents that are considered relevant. This study discusses the important thing in education, namely how the form of implementation of PKB in education, by organizing $P K B$ in accordance with the rules, it can improve the quality of education, especially in elementary schools. PKB is a learning that is carried out continuously by educators in an effort to realize changes associated with student success so that students have knowledge, skills and can find out material more optimally. Through the PKB program, educators can increase student motivation, especially in the field of science and technology. A competent teacher is needed to support the country's comprehensive development because it can produce intelligent people.
\end{abstract}

Keywords: PKB, teacher, education

Copyright (c) 2020 Kurnia Puspita Sari, Suryarma Marsidin, Ahmad Sabandi

$\triangle$ Corresponding author :

Address : Padang, Sumbar

Email : kurniapuspitasari248@gmail.com

ISSN 2656-8071 (Media Cetak)

Phone : 081276747068

ISSN 2656-8063 (Media Online)

DOI: $10.31004 /$ edukatif.v2i2.110

Edukatif : Jurnal Ilmu Pendidikan Vol 2 No 2 Tahun 2020 p-ISSN 2656-8063 e-ISSN 2656-8071 
114 Kebijakan Pengembangan Keprofesian Berkelanjutan (PKB) Guru di Sekolah Dasar - Kurnia Puspita Sari, Sufyarma Marsidin, Ahmad Sabandi

DOI: 10.31004/edukatif.v2i2.110

\section{PENDAHULUAN}

Pendidikan adalah suatu proses yang penting untuk mencerdaskan bangsa maka dari itu harus dilaksanakan oleh orang yang profesional. Satu diantara poin utama suatu organisasi pendidikan yaitu guru. Organisasi pendidikan tersebut perlu dan harus ditingkatkan sebagai suatu organisasi pembelajar. Hal tersebut dilaksanakan guna mempersiapkan atas transformasi yang akan terjadi kedepannya. Salah satu syarat penting dari terwujudnya organisasi pembelajar yaitu terbentuknya masyarakat pembelajar pada organisasi tersebut. Hal tersebut dikarenakan salah satu komponen tersebut merupakan bagian dari keseluruhan organisasi dan merupakan hasil dari kinerja seluruh komponen termasuk unsur SDM. Kaitannya dengan sekolah, baik itu individual ataupun bersama dengan guru lainnya wajib menjadi satu dari keseluruhan sistem baik secara sadar atau tanpa disadari secara terus menerus dalam beragam aktivitas belajar untuk meningkatkan kompetensinya. Sebagai wujud implementasi peran guru sebagai tenaga yang profesional agar dapat mengembangkan kompetensinya maka diselenggarakan program PKB agar dapat memperkecil jarak antara kompetensinya yang sekarang dengan apa yang menjadi tuntutan ke depan berkaitan dengan profesinya.

Permasalahan yang ditemukan, masih banyak guru terkendala dengan masalah kenaikan pangkat. Hal ini dikarenakan pelaksanaan PKB yang merupakan unsur utama dalam proses kenaikan pangkat belum maksimal dilaksanakan. Banyak guru yang belum mengerti fungsi dari PKB. Permasalahan lain yang terlihat kebanyakan guru setelah dilaksanakan program PKB belum optimal dalam meningkatkan kualitas pembelajaran di kelas sehingga kegiatan PKB belum berdampak terhadap sekolahnya. Sebenarnya apabila program ini dilaksanakan secara optimal dengan berkesinambungan maka akan melahirkan guru yang profesional sehingga pembelajaran dapat terselenggarakan dengan baik.

Beragam cara dalam meningkatkan kompetensi guru salah satunya melalui program PKB. Berkaitan dengan hal tersebut harapannya empat kompetensi guru meliputi pedagogik, profesional, sosial dan kepribadian dapat meningkat sehingga keinginan dan tuntutan guru dapat tercapai dengan optimal sesuai profesinya. Jika penilaian kinerja guru masih rendah sesuai dengan kriteria standar kompetensi maka guru diharuskan melaksanakan PKB difokuskan kepada pencapaian standar kompetensi guru. Dan jika hasil PK GURU mencapai standar maka aktivitas PKB diorientasikan pada peningkatan karir guru serta pemenuhan layanan pembelajaran yang bermakna. Berdasarkan pemaparan sebelumnya, dengan adanya PKB diharapkan guru dapat mengikuti perkembangan IPTEK dan sebagai penambahan pengetahuan, keterampilan dan sikap bagi guru untuk melaksanakan Tupoksinya sesuai standar kompetensi yang diharapkan.

Berdasarkan pemaparan diatas, karena pentingnya pemahaman tentang kebijakan PKB guru, maka diperlukan kajian studi perpustakaan untuk membahas hal tersebut. Untuk itu penulis tertarik dalam melakukan pembahasan dengan judul "Kebijakan Pengembangan Keprofesian Berkelanjutan (PKB) Guru". Tujuan pembahasan ini adalah untuk mendeskripsikan kebijakan 
115 Kebijakan Pengembangan Keprofesian Berkelanjutan (PKB) Guru di Sekolah Dasar - Kurnia Puspita Sari, Sufyarma Marsidin, Ahmad Sabandi

DOI: 10.31004/edukatif.v2i2.110

pengembangan keprofesian berkelanjutan (PKB) guru.

\section{METODE PENELITIAN}

Dalam penelitian ini menggunakan metodologi penelitian kepustakaan (library research). Penelitian berbasis literatur yaitu bentuk penelitian yang menggunakan literatur sebagai objek kajian. Ada beberapa ciri utama yang perlu diperhatikan dalam metode penelitian studi pustaka yaitu: Pertama, penulis dihadapkan langsung dengan teks/data angka. Kedua, bahan pustaka diartikan sebagai sumber kedua artinya penulis memperoleh informasi dari pihak kedua bukan orisinil dari pihak pertama di lapangan. Ketiga, data/informasi yang diperoleh bersifat "siap pakai". Keempat, bahan pustaka yang diperoleh tidak dibatasi ruang dan waktu (Zed, 2003). Dengan demikian, teknik pengumpulan data yang dilakukan dengan cara mengkaji beberapa buku, literatur serta dokumen lain yang dianggap sesuai dengan kajian di atas.

\section{HASIL DAN PEMBAHASAN PENELITIAN}

\section{Definisi PKB}

Mengkaji PKB tidak terlepas dari unsur guru, guru adalah komponen utama dalam pendidikan baik tingkat institusi ataupun instruksional. Kehadiran guru dalam melaksanakan tugas sebagai pendidik berperan penting dalam penyelenggaraan proses pendidikan. Menurut Baedhowi (2010), jika tidak ada guru maka pendidikan hanya sebagai slogan artinya tidak berarti apa-apa. Sebagai tenaga profesional yang memiliki peran penting, guru berkedudukan penting dalam memanifestasikan individu cerdas dan berkualitas.

Program PKB dilaksanakan dari PK GURU disertai hasil evaluasi diri. PKB diyakini sebagai komponen utama sesudah aktivitas pembelajaran serta beban sesuai dengan peran sekolah berdasarkan angka kredit guru terutama yang berkaitan dengan peningkatan karir guru terkhusus dalam peningkatan pangkat guru.

PKB merupakan komponen utama dalam pendidikan yang programnya dikenakan angka kredit dalam peningkatan karir guru secara cakap. PKB meliputi kegiatan pengembangan diri, publikasi ilmiah dan karya inovatif. Diluar PKB beragam program dalam peningkatan karir dan mutu pendidik contohnya Penelitian Tindakan Kelas (PTK), lesson study.

\section{Komponen PKB}

Menurut Gultom (2012) berikut dijelaskan beberapa komponen dari PKB yaitu:

1. Pelaksanaan Pengembangan Diri

Segala daya dalam mengembangkan profesionalisme diri agar mempunyai potensi berkaitan dengan undang-undang hingga dapat menyelenggarakan tupoksi serta beban pembelajaran serta pengerjaan tugas lain sesuai dengan peran sekolah. Kegiatannya terdiri dari diklat fungsional dan kegiatan kolektif guru. Diklat fungsional artinya aktivitas pendidik untuk pelaksanaan latihan dengan tujuan mencapai standar kompetensi yang dibebankan serta mengembangkan profesi guru dalam rentang periode terentu. Kegiatan kolektif guru yaitu 
116 Kebijakan Pengembangan Keprofesian Berkelanjutan (PKB) Guru di Sekolah Dasar - Kurnia Puspita Sari, Sufyarma Marsidin, Ahmad Sabandi

DOI: 10.31004/edukatif.v2i2.110

aktivitas guru pada aktivitas ilmiah guna mewujudkan kriteria yang dibebankan.

Kedua program di atas harus mementingkan kepentingan guru dalam pengembangan keprofesian pelaksanaan layanan pembelajaran.

2. Pelaksanaan Publikasi Ilmiah

Publikasi ilmiah yaitu tulisan rasional lalu dipublikasi pada orang banyak sebagai wujud peran serta pendidik untuk meningkatkan mutu dan proses belajar mengajar di sekolah. Bentuk kegiatan publikasi ilmiah meliputi 3 garis besar yaitu: a) penyampaian kepada kelompok ilmiah, selaku pembicara pada seminar, aktivitas ilmiah, b) publikasi ilmiah pada bidang formal. Programnya meliputi, 1) tulisan yang berbentuk artikel pendidikan, 2) catatan ilmiah pada bidang pendidikan formal di terbitkan tingkat nasional baik terakreditasi/tidak serta dalam cakupan lokal, c) penerbitan referensi belajar, sumber pendalaman materi dan petunjuk guru. Penerbitan meliputi, 1) referensi belajar tiap jenjang/referensi per judul, 2) modul belajar tiap semester, 3) referensi yang dicetak penerbit ber-ISBN dan/atau tidak, 4) literatur terjemahan yang disetujui oleh kepsek/madrasah tiap karya, 5) literature petunjuk bagi pendidik.

\section{Pelaksanaan Karya Inovatif}

Karya inovatif yaitu sesuatu yang sifatnya perluasan, variasi/ menemukan sebagai wujud ikut serta guru dalam meningkatkan mutu pembelajaran pada dunia pendidikan. Bentuk karya ini meliputi, a) penciptaan teknologi daya guna yang kompleks/sederhana, b) penciptaan karya seni, c) penciptaan media belajar golongan kompleks/sederhana, d) pembentukan kriteria, petunjuk tes ataupun lainnya di tingkat nasional ataupun provinsi.

\section{Prinsip Dasar Pelaksanaan PKB}

Menurut Fajarwati (2019) beberapa prinsip dasar dari pelaksanaan PKB yaitu: 1) PKB difokuskan pada kesuksesan siswa/capaian belajar siswa. Maka dari itu, PKB sebagai bagian dari tugas guru, 2) Tiap guru berhak memperoleh peluang dalam pengembangan diri secara sistematis dan kontiniu. Untuk menghindari kesempatan yang sama dalam program PKB guru maka penyusunan kegiatan PKB dimulai di sekolah, 3) Seperti dijelaskan sebelumnya bahwa guru berhak mengikuti PKB, untuk pelaksanaan PKB tersebut dilakukan minimal jumlah jam per tahun sesuai ketetapan peraturan pemerintah, 4) setelah dilaksanakan penilaian kinerja guru, jika guru tersebut termasuk kategori mengikuti PKB apabila ia tidak melaksanakannya maka akan diberikan sanksi, 5) materi PKB berfokus pada pembelajaran siswa, materi akademik, pendekatan pembelajaran, model terkini untuk meningkatkan mutu pendidikan, 6) PKB diawali pada guru itu sendiri, maka aktivitas pengembangan melibatkan guru dengan aktif hingga terdapat perubahan bagi diri guru tersebut, 7) PKB memberikan sumbangan terhadap perwujudan tujuan serta nilai yang berlangsung di sekolah yang bersangkutan. Maka dari itu PKB patut sebagai salah satu komponen penting berkaitan perencanaan peningkatan pendidikan, 8) PKB diupayakan dilakukan di sekolah/bersama sekolah di 
117 Kebijakan Pengembangan Keprofesian Berkelanjutan (PKB) Guru di Sekolah Dasar - Kurnia Puspita Sari, Sufyarma Marsidin, Ahmad Sabandi

DOI: 10.31004/edukatif.v2i2.110

lingkungannya dikarenakan untuk relavansi kegiatan, 9) PKB seharusnya dapat mewujudkan legalisasi profesi guru menjadi lebih bermartabat serta berguna untuk mendidik anak sehingga menciptakan perubahan khususnya di bidang pendidikan.

\section{Tujuan PKB}

Menurut Danim (2002) tujuan umum dari PKB yakni memajukan mutu pendidikan di sekolah dalam upaya peningkatkan kualitas pendidikan. Tujuan khususnya yaitu: a) mengembangkan potensi pendidik dalam mewujudkan standar kompetensi yang ditentukan dalam ketetapan aturan, b) memperbaharui potensi pendidik dalam pemenuhan keperluan akan pertumbuhan IPTEKS, c) mengembangkan tanggung jawab guru pada pelaksanaan TUPOKSI sebagai profesi yang professional, d) Membangkitkan wujud cinta serta bangga dalam menyandang jabatan guru, e) mendorong peningkatan karir guru.

\section{Lingkup Pelaksanaan Kegiatan PKB}

Berikut ini cakupan aktivitas PKB yang bisa dilaksanakan di sekolah yaitu (Kemendiknas, 2012):

1. Dilaksanakan oleh guru sendiri mencakup: a) memodifikasi kurikulum meliputi pokok terkini mengenai teknologi serta sains berkaitan keinginan siswa, b) merancang serta melakukan PBM yang berorientasi kepada peserta didik, c) memperkirakan serta menelaah rekapitulasi belajar siswa sebagai gambaran potensi siswa secara keseluruhan, d) mengkaji serta mengembangkan model pembelajaran berdasarkan respon siswa dari pembelajaran yang telah dilaksanakan, e) menyusun aktivitas pembelajaran sebagai objek untuk melakukan renungan serta modifikasi pembelajaran, f) menelaah dan membaca berbagai jurnal/referensi lain sesuai dengan profesi dalam rangka kegiatan pengembangan pengetahuan, g) melakukan penyelidikan mandiri dan dituliskan hasilnya dalam bentuk catatan yang terstruktur.

2. Dilaksanakan oleh guru bersama guru lain dalam sekolah yang sama, meliputi: a) sama-sama mengamati serta membagikan masukan sebagai pertimbangan pembelajaran, b) melaksanakan pengenalan, penyelidikan yang mengkaji persoalan yang ditemui di kelas, c) menyusun modul, buku pedoman siswa, LKPD dsb, d) membahas jurnal/buku sesuai dengan bidang serta profesinya untuk mendukung peningkatan pembelajaran, e) melakukan modifikasi kurikulum serta melakukan persiapan mengajar.

\section{Prosedur PKB}

Mekanisme PKB yang diharapkan bisa mengisi kebutuhan guru dalam pengembangan keprofesionalismenya (Suryani, 2017):

Langkah 1. Guru melaksanakan penilaian diri tiap permulaan tahun untuk melihat kinerja guru sebelumnya. Setiap guru tidak terkecuali guru yang baru mengajar juga 
118 Kebijakan Pengembangan Keprofesian Berkelanjutan (PKB) Guru di Sekolah Dasar - Kurnia Puspita Sari, Sufyarma Marsidin, Ahmad Sabandi

DOI: 10.31004/edukatif.v2i2.110

harus melaksanakan penilaian kinerjanya pelaksanaannya bisa permulaan tahun ajaran baru/sebelum penghujung tahun ajaran. Kemudian pendidik yang dikenakan beban mengajar lebih dari satu sekolah lalu aktivitas penilaian,

Langkah kedua setelah dilaksanakan penilaian diri, selanjutnya guru mengikuti evaluasi kinerja formatif. Evaluasi ini dibutuhkan dalam penentuan riwayat kinerja guru untuk menentukan apa guru yang bersangkutan berhak mengikuti kegiatan pengembangan kinerja dalam rangka pencapaian standar potensi lanjutan.

Langkah ketiga. Lewat diskusi bersama kepsek (dengan ketentuan koordinator PKB yaitu pendidik yang diberikan amanah oleh Kepsek). Pendidik dan koordinator PKB harus menyusun aktivitas PKB (untuk diajukan bersama koordinator PKB Kabupaten/Kota).

\section{Langkah ke empat. Ketua PKB}

Kab/Kota, kepsek, ketua MGMP dan ketua PKB sekolah menentukan serta mengesahkan perencanaan dari PKB yang sifatnya final meliputi aktivitas PKB yang dilaksanakan oleh guru sendiri/bersama pendidik lainnya dengan sekolah yang sama menjadi bagian dari aktivitas yang dilaksanakan oleh suatu sekolah, aktivitas ini kemudian diorganisasikan oleh KKG/MGMP.. Terkhusus aktivitas PKB yang dilakukan tingkat kab/kota mulanya didiskusikan pada koordinator dinas pendidikan untuk mendapatkan kesepakatan. Kemudian direncanakan anggaran program PKB dilakukan di kab/kota serta memberikan anggaran kepada sekolah dalam penyelenggaraan PKB baik dilakukan secara independen atau dengan aktivitas terhimpun dalam sekolah.

Langkah kelima, guru kemudian menyetujui program PKB meliputi aktivitas yang dilaksanakan dalam/luar sekolah, setelah dipelajari dan disetujui oleh ketua PKB Kab/Kota, kepsek, ketua KKG dan coordinator sekolah sesuai hasil pembahasan dengan dinas. Setiap pendidik berhak untuk memperolah pembinaan berkesinambungan dari guru senior pada pelaksanaan pembelajaran yang sudah tercapai standar yang berlaku dan mempunyai ketentuan kinerja minimum baik dari PK Guru yang berlaku.

Langkah Keenam, guru wajib melaksanakan aktivitas PKB seperti diagendakan dalam/luar sekolah. Kemudian sekolah memiliki tanggung jawab dalam menjamin kesibukan guru dalam pelaksanaan program $\mathrm{PKB}$ dan tidak menurunkan mutu PBM siswa di kelas. Perlu diperhatikan ada variasi antara penyelenggaraan PKB untuk guru nilai PKnya telah mencapai/lebih standar kompetensi dengan dibawah standar. Bagi guru yang mempunyai nilai PK nya sesuai standar/lebih akan mengikuti program PKB yang berorientasi kepada peningkatan ilmu pengetahuan agar dapat memberikan layanan pendidikan yang optimal. Sedangkan guru dengan nilai PK di bawah ketetapan memperhatikan: a) bentuk kompetensi yang perlu dikembangkan, b) dukungan yang diberikan sekolah, c) hasil penilaian PK GURU, d) sasaran peningkatan yang diinginkan 
119 Kebijakan Pengembangan Keprofesian Berkelanjutan (PKB) Guru di Sekolah Dasar - Kurnia Puspita Sari, Sufyarma Marsidin, Ahmad Sabandi

DOI: 10.31004/edukatif.v2i2.110

setelah melaksanakan program PKB dalam peningkatan kompetensi/keahlian lain dalam usaha mencapai standar kompetensi.

Proses perencanaan PKB dalam rangka mewujudkan standar kompetensi terkhusus bagi guru yang nilai PK GURU rendah maka perlu mencantumkan proses pelaksanaannya dan didampingi dengan mentor baik berasal dari sekolah ataupun di luar sekolah.

Langkah ke tujuh, Implementasi proses peninjauan dan penilaian program PKB dilakukan oleh Ketua PKB Kabupaten/Kota bersama ketua PKB jenjang sekolah, melihat apakah program PKB yang diselenggarakan tujuannya telah tercapai/belum, sudah tercapai sesuai prediksi, melihat keunggulan serta persoalan yang ditemui dan penggunaan hasil dari program PKB bagi guru dalam melaksanakan tugasnya serta penilaian dampak dari usaha pengembangan mutu pendidikan di sekolah.

Langkah ke delapan, sesudah melaksanakan kegiatan $\mathrm{PKB}$, guru harus melakukan PK pada penghujung tahun akademik baru. Hasil PK tersebut disetarakan pada pemberian angka kredit. Kombinasi angka yang diperoleh dan kegiatan yang dilaksanakan dihitung untuk naik pangkat sebagai masukan dalam menentukan tambahan tugas/sangsi bagi pendidik. PK guru ditentukan oleh penilai, sedangkan angka kredit ditentukan ketua PKB pada jenjang sekolah melihat pada petunjuk pembobotan angka kredit.

Langkah ke Sembilan, pada penghujung tahun, pendidik serta ketua PKB melaksanakan perenungan, apa program PKB yang telah dilakukan berguna dalam mewujudkan karya sifatnya saintifik/terbaru.

\section{KESIMPULAN}

Guru memerlukan keterampilan pada pengembangan pembelajaran. Guru juga harus mempunyai ciri khas dalam membimbing. PKB adalah sustu tempat dalam mewadahi guru untuk mengembangkan potensinya nantinya memberikan pengalaman yang bermakna bagi pendidik. Karena PKB memberikan pengalaman secara berkesinambungan sebagai jalam utama dalam mewujudkan perubahan yang berkenaan dengan siswa. Menjadi pendidik tidak boleh beranggapan untuk tidak lanjut belajar seharusnya karena menjadi pendidik maka senantiasa belajar dalam rangka pengembangan kompetensi yang dimiliki. Maka dari itu PKB merupakan jalan untuk meningkatkan mutu agar tercapainya pendidikan yang optimal dan melahirkan SDM yang cekatan diserta siswa dengan dedikasi unggul.

\section{DAFTAR PUSTAKA}

Baedhowi. (2010). Pedoman Pengelolaan Pengembangan Keprofesian Berkelanjutan (PKB) Kementerian. Kementerian Pendidikan Nasional.

Danim, S. (2002). Inovasi Pendidikan, Dalam Upaya Peningkatan Profesionalisme Tenaga Kependidikan. Pustaka Setia.

Fajarwati, D. (2019). Rencana Pengembangan Keprofesian Berkelanjutan (MPPKS-PKB). Direktorat Jenderal Guru dan Tenaga Kependidikan.

Gultom, S. (2012). Pedoman Pengelolaan Pengembangan Keprofesian Berkelanjutan. Badan PSDMP dan PMP. 
120 Kebijakan Pengembangan Keprofesian Berkelanjutan (PKB) Guru di Sekolah Dasar - Kurnia Puspita Sari, Sufyarma Marsidin, Ahmad Sabandi

DOI: $10.31004 /$ edukatif.v2i2.110

Kemendiknas. (2012). Pedoman Pengelolaan Pengembangan Keprofesian Berkelanjutan $(P K B)$. Kementerian Pendidikan dan Kebudayaan.

Suryani, N. (2017). Strategi Pembimbingan Materi PKB untuk Guru. Lembaga Pengembangan dan Pemberdayaan Kepala Sekolah (LPPKS).

Zed, M. (2003). Metode Penelitian Kepustakaan. Yayasan Obor Indonesia. 